\section{A.R.P. Wardens' Warning System}

THE life of an A.R.P. warden is in general a strenuous one. Night after night he may be called from his bed for alarms real and false. Many nights also are spent at a post on stand-by duty, which, but for the present call-up system, could have been passed in the comfort of his home. In the Electrician of September 6, it is recalled that some years before the War many local authorities installed special control systems for street lighting which at the time, it was anticipated, would be permitted to be used in the event of the outbreak of hostilities. These systems were described in the E'lectrician and each one incorporated a signalling arrangement for calling fire and ambulance services, police, wardens and other A.R.P. workers. Unfortunately, the complete black-out of our streets ordered last September rendered the control system of little immediate use, though we learn that the wardens' call unit which forms a component of the system is being used in at least one provincial town. This unit consists of a plug-in device for insertion in a lamp-holder and is carried by the warden as part of his equipment. Whether he is at home, or at the house of a friend, plugging the unit in the supply network puts him within calling range of the A.R.P. authorities, whenever wanted, by its response to a D.c. impulse transmitted over the mains from the local control point.

Any device which will permit A.R.P. workers to spend more time at home will tend to improve the efficiency of the civil defence service as a whole, for with proper rest and normal social intercourse, those who man the service will be better able to meet the demands upon their time and energies. There must be many local authorities with similar systems installed but not yet in use, and it is suggested that regional commissioners sanction their employment at once. Those authorities who are as yet without such call-up systems should in their turn be prevailed upon to bring their local defence arrangements in line. For their information it may be mentioned that the systems cost relatively little to instal, and the call-up units less. The increase in efficiency of the A.R.P. service turn-out in the case of a preliminary or general alarm is out of all proportion to the expenditure involved.

\section{Physical Society Colour Group}

Aт a meeting held on May 16, under the authority of the Council of the Physical Society and attended by a number of those interested in colour problems, it was unanimously agreed to form a Group with the title of "The Physical Society Colour Group". The objects of this Group will be to provide an opportunity for the various groups of people concerned with colour-physicists, chemists, industrialists, etc.--to meet and become familiar with each other's problems, to enable a representative opinion to be formed on various questions of standardization, specification, nomenclature, etc., and generally to encourage colorimetric investigations and to ensure that this country shall keep abreast of developments abroad. At the above meeting the following officers of the
Group were elected : Chairman, Dr. W. D. Wright ; Hon. Secretary, Mr. H. D. Murray ; Committee, Mr. H. W. Ellis, Mr. J. Guild, Mr. J. G. Holmes.

It will be appreciated that the objects envisaged in the formation of this Colour Group can best be achieved by co-operation of all those interested in colour problems, in whatever field these problems may arise. For this reason, it is felt by those responsible for the formation of the Group that it should be regarded as a meeting ground for all in science and industry who have a common interest in colour, rather than as a self-contained and independent society. Accordingly, a number of societies have been invited to become founder societies of the Group and to co-operate in its activities. It is hoped to hold the first general meeting of the Group, to be followed by the first scientific meeting, in the middle of October. The general subject for discussion will be "Colour Tolerance". Further information can be obtained from Mr. H. D. Murray, Physical Society, 1 Lowther Gardens, Exhibition Road, London, S.W.7.

\section{Highway from Alaska to the Argentine}

A wide high-speed double-track road from Alaska to the Argentine is proposed by the American Automobile Association as an important factor in plans for the defence of the Americas. In a letter to Senator Morris Sheppard, chairman of the Senate Military Affairs Committee, and Mr. Andrew J. May, chairman of the House Military Affairs Committee, Mr. Thomas P. Henry, president of the Association, stated that along many stretches of the proposed route, the road is already built. He urged that the linking up of these separate sections should be undertaken with the least possible delay.

"For many years," he wrote, "American motorists have been looking forward to the eventual completion of an All-America Highway from Alaska to the Argentine, connecting the lands of the Western Hemisphere. Hitherto it has been regarded mainly as a tourist asset, a means of opening up new travel objectives and as a promoter of friendship between the various peoples. But the present world crisis puts an entirely new light on the project. The United States, embarked already on a programme of building up its national defences, and pledged to protect the entire hemisphere against aggression, has a greater need of the highway than ever before".

\section{Depopulation in France}

IN a recent thesis (Thèse de Paris 1940, No. 311) Dr. H. Birnbaum remarks that for more than a century the population of France has shown only a very slight increase; from 34 millions in 1840 it has risen to only 42 millions in 1940. At the same time there has been a very pronounced fall in the annual number of births, namely, from about a million in 1840 to a little more than half that number in 1939 . During the same period owing to the progress of medicine and hygiene as well as of certain technical acquisitions the average duration of human life has increased by about twenty years, so that the average span of life in 1940 is about 60 years as compared 
with 40 in 1840. According to Dr. Birnbaum, de. population in France is due to individual and voluntary limitation of births, whether this limitation is due to anticonceptional measures or to criminal abortions, of which latter more than 300,000 are carried out on married women in France every year.

\section{Retail-Store Training}

A Bulletrn by K. B. Haas (Vocational Division Bulletin No. 205, Business Education Series No. 12) which has been issued by the Office of Education, United States Department of the Interior, under the title "Co-operative Part-Time Retail Training Programmes", reviews the history and progress of retailstore training programmes. It discusses the need for training programmes in secondary schools and extension classes and describes the kinds of training programmes which have prospects of success. Proved methods for promoting, initiating, co-ordinating, supervising and teaching the various types of retailtraining courses in different communities are indicated as well as both the factors contributing to the success of such programmes and mistakes which have been made. The qualifications necessary for teachers of such subjects are discussed, and emphasis is placed on the co-operative part-time type of instruction on the secondary level.

\section{The Colonial Service: Recent Appointments}

THE following appointments and promotions in the Colonial Service have recently been made: P. G. Coleman, agricultural officer, Malaya; M. D. ffrenchMullen, agricultural officer, Fiji; F. B. Leech, veterinary officer, Nyasaland; G. C. L. Bertram, chief fisheries officer, Palestine; C. L. Gulliver, meteorological assistant, Nigeria; A. S. Richardson (deputy director of Agriculture, Uganda), director of agriculture, Nyasaland; D. H. Hodgson (conservator of forests), deputy director of forests and deputy adviser on forestry, Malaya; H. E. C. Lushington (assistant conservator of forests), senior assistant conservator of forests, Ceylon; J. G. Watson (deputy director of forests and deputy advisor on forestry), director of forests and adviser on forestry, Malaya.

\section{The Night Sky in October}

THe moon is new on October 1 and 30 and full on October 16. Jupiter and Saturn are in conjunction with the moon on October 18d. 0h. and Venus on 28d. 4h. U.T. The 4th magnitude star, $\alpha$ Cancri, is occulted on October 25, the disappearance occurring at $1 \mathrm{~h} .48 \cdot 3 \mathrm{~m}$. (at position angle $116^{\circ}$ from the north point) and the reappearance at $2 \mathrm{~h} .49 \cdot 8 \mathrm{~m}$. at position angle $267^{\circ}$. Jupiter and Saturn, still close together, rise before $18 \mathrm{~h}$. in mid-October. These two planets are in conjunction with one another on October 11 at $23 \mathrm{~h}$., but their closest approach $\left(1 \cdot 2^{\circ}\right)$ occurs on October 19. Close groupings of Jupiter's four inner satellites can be seen at $0 \mathrm{~h} .15 \mathrm{~m}$. on October 3, 4, 11,12 and 19 (all to the eastward side), 21, 28 and 29. Examples of wide separation occur on October $6,8,15$ and 31 . Venus, the brilliant planet rising about four hours before the sun, is close to Regulus on October 6 and near $\beta$ Virginis on October 29 . Conjunction with Neptune is on October 29 at $21 \mathrm{~h}$. The Orionid meteors reach their maximum frequency about October 19, the radiant point being north, following $\alpha$ Orionis (Betelgeuse).

The new moon on October 1 is associated with a total eclipse of the sun, the path of totality, some 120 miles wide, crossing Brazil, the South Atlantic to South Africa. The duration on the Brazilian coast will be 5 minutes; north-east of East London, South Africa, the duration is $3 \mathrm{~min} .24 \mathrm{sec}$. A general article referring to arrangements for observing the eclipse appears on p. 422 of this issue.

\section{Announcements}

Among the changes in the Schedule of Reserved Occupations recently announced is the statement that scientific and research workers may now volunteer for general service in the armed forces irrespective of age, provided that consent is obtained from the Committee for Scientific Research of the Central Register Advisory Council.

DURING the continuance of the present disturbed conditions, the library of the Chemical Society at Burlington House, London, will be closed on Saturdays. So far as circumstances permit, it will be open on other weekdays from 10 a.m. until 5 p.m.

THE Rockefeller Foundation has given $£ 1,000$ to the Royal Society of Medicine for the preservation of its library. It is proposed to evacuate to a suitable house a number of the older and irreplaceable periodicals. A member of the library staff will accompany them and will be in telephonic communication with the library in London.

The fourth Pan-American Congress of the Red Cross will be held at Santiago, Chile, during December 5-14 under the direction of General L. Brieba, president of the Central Committee of the Red Cross in Chile.

MANY valuable zoological collections recently gathered in Central America for the British Museum are being housed in the Field Museum of Natural History, Chicago. After an expedition headed by Ivan T. Sanderson, of Belize, British Honduras, had completed its work of collecting mammals, reptiles and various invertebrate animals in Central America, the War made it unsafe to ship them to England. The Field Museum, therefore, offered its hospitality, and the first large instalment of Mr. Sanderson's material has recently arrived there. Some of it is to be classified there, at his request, and ultimately some division of the collections will be made between the Field Museum and the British Museum.

THE International Commission on Zoological Nomenclature has commenced the publication of the Opinions rendered by the Commission, vol. 2, Opinions 134-136. Copies may be obtained from the Commission, c/o Royal Entomological Society of London, 41 Queen's Gate, South Kensington, London, S.W.7. 